\title{
Milli Eğitim Bakanlığı Yönetici ve Uzmanlarının Görüşlerine Göre Türkiye'de Eğitim Politikalarını Geliştirme Sürecinin Değerlendirilmesi*
}

\author{
Evaluation of the Education Policy Development Process in Turkey \\ According to the Views of Ministry of National Education Managers \\ and Specialists
}

\begin{abstract}
Hakan UYSAL**
Öz: Bu araştırmanın amacı, Türkiye'de eğitim politikalarının geliştirilmesi sürecini değerlendirmektir. Çalışmada nitel araştırma yöntemi kullanılmıştır. Araştırmanın katılımcıları Milli Eğitim Bakanlığının farklı kademelerinde görev yapan 4'ü uzman ve 34'ü yönetici olmak üzere toplam 38 kişidir. Katılımcıların görüşlerini almak üzere sekiz temel sorudan oluşan görüşme formu hazırlanmıştır. Veriler yüz yüze yapılan görüşmelerde yarı yapılandırılmış sorularla toplanmıştır. Bir katılımcı ise soruları yazılı olarak cevaplandırmıştır. Katılımcıların görüşleri araştırmacı tarafından kayıt altına alınmıştır. Elde edilen görüşler araştırmanın görüşme soruları temelinde betimsel analiz ile çözümlenmiş, ana ve alt temalara ayrılarak yorumlanmıştır. Araştırma sonuçlarına göre; Türkiye'de eğitim politikalarının belirlenmesinde ve kamuoyu gündemine gelmesinde siyaset ve sivil toplum kuruluşları etkili olmaktadır. Belirlenen ve kamuoyu gündemine gelen eğitim politikalarının uygulanmasına yönelik kararlar almak için çeşitli kişi, kurum ve kuruluşlardan görüşler alınmaktadır. En fazla görüş sivil toplum kuruluşlarından alınmaktadır. Eğitim politikalarının uygulamaya geçebilmesi için en fazla sorumluluğu Milli Eğitim Bakanlığı ve siyaset almaktadır. Eğitim politikasının uygulamaya konulabilmesi için bazı koşullar yerine getirilmektedir. Bu koşulların başında "pilot uygulamaların yapılması" ve "fiziki koşulların yerine getirilmesi" gelmektedir. Uygulamaya konulan eğitim politikaları merkez teşkilatınca izlenmektedir. Uygulamaya konulan eğitim politikalarının izlenmesinde ortaya çıkan olumsuzluklara müdahale edilmektedir. Uygulanan eğitim politikaları, Milli Eğitim Bakanlığı'nın ilgili birimlerinin araştırma ve raporları ile değerlendirilmektedir. Ancak katılımcılar değerlendirme sonuçlarına göre politikalarda değişiklik yapılıp yapılmadığı konusunda kararsızdırlar.
\end{abstract}

Anahtar Kelimeler: Eğitim politikası, politika belirleme, politika gündemi, politika belirleme süreci, eğitim politikası süreci

\begin{abstract}
The aim of this study is to evaluate the development process of education policies in Turkey. Qualitative research method has been used in the study. Participants of the survey are 38 persons, 4 of whom are experts and 34 of whom are administrators at different levels of the Ministry of National Education. An interview form consisting of eight basic questions has been prepared to receive the views of the participants. Data have been collected through semi-structured questions at face to face interviews. Only one participant answered the questions in written. The views of participants have been recorded by the researcher. The obtained opinions have been analyzed via descriptive analysis by following interview questions and they have been interpreted by being separated into main theme and subthemes. According to the results of the research; in determining the educational politics in Turkey and bringing to them the attention of the public, civil society organizations and policy are efficient. Opinions are taken from various people, institutions and organizations in order to make decisions on the implementation of education policies that are determined and come to the public agenda. The most views are taken from non-governmental organizations. The Ministry of National Education and politics take the most responsibility for the implementation of educational policies. Some conditions are fulfilled in order to put education policy into practice. Two conditions are the leading; "pilot applications" and "fulfilling physical conditions". The education policies that are put into practice are monitored by the central

\footnotetext{
* Bu makale Eğitim Yöneticilerinin ve Uzmanlarının Görüşlerine Göre Türkiye'deki Eğitim Politikalarının Değerlendirilmesi konulu doktora tezinden üretilmiştir.

** Eğitim Uzmanı, Milli Eğitim Bakanlığı, Din Öğretimi Genel Müdürlüğü, Ankara-Türkiye, ORCID: 0000-0001-

7413-0658, e-posta: balkaroglu06@gmail.com
} 
organization. In monitoring of the education policies put into that are practice, the negativities are intervened. Implemented educational policies are evaluated through the researches and reports of relevant departments of the Ministry of National Education. However, according to the results of the evaluation, participants are hesitating whether the policy has been changed or not.

Keywords: Education policy, policy setting, policy agenda, policy setting process, education policy process

\section{Giriş}

Ülkelerin gelişmişlik düzeyleri ile eğitim arasında doğrudan bir ilişki olduğu bilinen bir gerçektir. Bu nedenle iletişim ağları ile ülkelerin birbirine bağlandığı ve dünyanın herhangi bir ülkesinde meydana gelen bir olayın, binlerce kilometre uzaklıktaki başka bir ülkeyi yakından ilgilendirdiği ve etkilediği günümüzde, ülkeler ihtiyaç duydukları insan gücünü yetiştirmek ve diğer ülkelerle rekabet gücünü geliştirmek için eğitime daha fazla önem vermektedirler. Çünkü bir ülkenin kalkınması nitelikli insan gücüne sahip olmasına bağlıdır. Hoşgörür (2005), eğitimin bu konudaki önemine dikkat çekmekte ve eğitimin eğitilmiş insan gücünü hazırlayan önemli araç olduğuna vurgu yapmaktadır. Adem (1995) de eğitimin bir başka işlevine dikkat çekmekte ve eğitimin sosyal adalet, firsat ve olanak eşitliği ilkelerini gerçekleştirmede en etkili araç olduğunu belirterek eğitim konusunun günümüzde de gelecekte de önemli olduğunu vurgulamaktadır. Kavak (2010) da eğitimin ülkeler için önemini şöyle belirtmektedir: "Ülkeler insana yaptıkları yatırımlarla kendilerini yeniden inşa etmektedirler. İyi eğitilmiş ve yetiştirilmiş bir nüfus, hem bireylerin ve toplumların refahı hem de insan hakları, demokrasi ve özgürlüklerin geliştirilmesi, yaşam beklentisi, toplumsal bütünleşme ve çevrenin korunması için gereklidir" (s. 17).

Gerek gelişmiş, gerekse kalkınmakta olan ülkeler, eğitimi ülke kalkınmasında önemli bir araç olarak görmektedirler. Çünkü insanları geliştirmek, onlara kalkınmaya uygun davranışlar kazandırmak ancak eğitimle mümkün olmaktadır (Kaya, 1995). Adem (1995), ekonomik açıdan eğitimi, ekonomik ve toplumsal kalkınmanın gerçekleştirilmesi için yeterli sayıda ve nitelikte insan gücü yetiştirme süreci olarak tanımlarken Sezgin (2001) ise kalkınmanın hızlandırılması, istihdamın ve ulusal rekabet gücünün arttırılmasının temel araçlarından birisinin eğitim olduğunu vurgulamakta, beşeri kaynağın çağın ihtiyaçları doğrultusunda geliştirilememesinin uzun dönemde telafisi güç problemlere neden olacağını belirtmektedir.

Eğitim, gelecek için bir yatırımdır. Eğitimin bir yatırım olduğu görüşleri Adam Smith’e kadar uzanmaktadır. Bununla birlikte, 1950'li yılların sonlarına doğru ortaya çıkan insan sermayesi kavramı, eğitim ile ekonomi arasındaki ilişkileri yeniden canlandırmıştır. Becker (2002) da insan sermayesinin önemine vurgu yapmış ve yaşadığımız çağı "insan sermayesi çağı" olarak nitelendirmiştir. Ona göre, ekonomilerin başarısı insana yapılan yatırımın etkililiğ i ile doğru orantılıdır (Akt. Kavak, 2010, s. 25).

Gümüş (2015) Türkiye'de eğitimin sosyo-ekonomik rolünün daima önemli, özellikle toplumu şekillendirmek ve ona yeni biçimler vermek hedefi doğrultusunda modernleşme sürecinde devletin önemli araçlarından biri olması nedeniyle üzerinde daima durulması gereken bir konu olduğunu belirtmektedir.

Eğitim insanların en temel haklarından birisidir ve devletler bu hakkı insanlara vermek zorundadır. Vatandaşlarına ihtiyaç duydukları eğitimi vermek de devletin temel görevlerindendir. Devlet bu görevini yerine getirirken sadece ülkedeki değil dünyadaki gelişmeleri de göz önünde bulundurmak durumundadır. Bugünün dünyasında eğitimi iyi bir şekilde değerlendirmek küresel dünyada toplumların iç içe yaşadığını dikkate almakla mümkündür (Hansen, 2008).

Gür (2011), Türkiye'de bugüne kadar izlenen eğitim politikaları dikkate alındığında milli eğitimin bütüncül bir sistem olarak ele alınmadığını, dolayısıyla sistemin unsurları üzerinde yapılan değişikliklerin, sistemin diğer unsurları üzerindeki etkisinin yeterince analiz edilmeden yürürlüğe konulduğunu söylemektedir. Gümüş (2015) de eğitim politikaları ile siyaset ilişkisi konusundaki görüşünü şöyle dile getirmektedir: 
"Siyasi yapı toplumsal değişim ile dönemsel dinamikler eğitim politikaları üzerinde etkili olmaktadır. Türk eğitim tarihinde dönemin iktidar partileri başta olmak üzere, dünyayla paralel olarak yaşanan toplumsal değişimlerin eğitim politikalarının belirlenmesinde etkili olduğu görülmektedir. Özellikle de siyasi yapının ideolojisi, politik anlamda eğitimin programlanmasında ve uygulanmasında oldukça etkili olmuştur. Günümüzde de eğitim politikaları hükümet politikaları ile paralel yürümeye başlamış, bu durum eğitimde istikrarsızlığı doğurmuştur. Bu istikrarsızlık beraberinde pek çok sorunu da beraberinde getirmiştir." ( s. 5).

Türkiye'nin üzerinde uzlaşılmış bir eğitim politikasının olduğunu söylemek güçtür. Milli eğitim bakanlarının sıklıkla değişmesi bunun bir göstergesidir. Değişen sadece bakanlar değil, aynı zamanda bakanlarla birlikte eğitim politikalarıdır. Bu yüzden eğitim sisteminde istenen hedeflere bir türlü ulaşılamamaktadır. Türk Eğitim Sistemindeki uygulamalar geçmişten bugüne kadar incelendiğinde, var olan sorunların temelinde eğitim politikalarının niteliğine yönelik bir takım sorunların olduğu söylenebilir.

Çevik (2013) “Gelişmiş Ülkelerde ve Türkiye'de Kamu Politikası Başarısızlığı” başlıklı makalesinde Türkiye'de ve diğer gelişmiş ülkelerde kamu politikasının başarısızlığının nedenleri üzerinde durmuş ve Türkiye'nin siyasal ve yönetim yapısı ile ekonomik sorunların kamu politikası başarısızlığına etkilerini açıklamıştır.

Sarı (2015) da "Türkiye'de Eğitim Politikalarının Aktörleri” başlıklı makalesinde Türk eğitim sistemi açısından milli eğitim şuraları ve Devlet Planlama Teşkilatınca (DPT) hazırlanan beş yıllık kalkınma planlarının eğitim politikalarını yönlendiren organizasyon ve programlar içinde en etkili süreçleri oluşturduklarını ileri sürmüş ve bunların eğitim politikalarını nasıl etkiledikleri üzerinde durmuştur. Sarı, ayrıca tarihi süreç içerisinde devletin eğitime müdahalesi ve eğitim politikalarında hükümet politikalarının etkisini açıklamıștır. Aynı makalede Sarı, eğitim politika ilişkisi ve eğitim politikalarında siyasi partilerin ve sivil toplum kuruluşları ve eğitim sendikalarının politika yapmadaki rollerini belirtmiş, eğitim politikalarına etki eden dış aktörler olarak Dünya Bankasının (DB) ve Avrupa Birliğini (AB) Türk eğitim politikalarını nasıl etkilediğini açıklamıştır.

Wigley ve Akkoyunlu'nun (2013), “Türkiye'de Eğitim Politikalarının Gelişimi ve Sonuçları" başlıklı makalelerinde, Türkiye'de eğitim politikalarının beşeri sermayenin geliştirilmesi veya bireylerin yapabilirliklerinin arttırılmasından ziyade Türk siyasetinin merkezindeki devlet elitlerinin ve Türk toplumunun "çevresini" temsil eden siyasi temsilcilerin ideal vatandaş konusundaki görüşlerini telkin etmeye çalışması ile şekillendiğini belirtmektedirler.

Nitekim bugüne kadar görev başına getirilen milli eğitim bakanları, eğitimle ilgili kendi parti politikaları hatta kişisel düşünceleri doğrultusunda değişiklikler yapmışlar, iktidardaki bir partinin politikalarını daha sonra gelen iktidarın bakanı, hatta bazen aynı partiye mensup bakanlar bile kendilerinden önceki politikaları değiştirmiş veya tamamen sonlandırmıştır.

Günümüzde karşı karşıya olduğumuz eğitim sorunları, eğitim politikalarımızın sorgulanması gereğini ortaya koymaktadır. Konuya ilişkin olarak Türkiye'de belirli dönemlerde geliştirilen eğitim politikası çalışmalarına rastlamak mümkündür. Ancak bugüne kadar eğitim politikalarının değerlendirilmesine ilişkin herhangi bir araştırma yapılmamıştır. $\mathrm{Bu}$ çalışma, eğitim politikalarının geliştirilmesiyle ilgili aksaklıkların ve problemlerin, Milli Eğitim Bakanlığının belirli kademelerinde görev yapmış ve halen yapmakta olan uzman ve yöneticilerin görüşleri doğrultusunda ortaya konulması açısından önemlidir. Araştırma sonuçları, Türkiye'de bundan sonra geliştirilecek eğitim politikalarına ve konu ile ilgili yapılacak çalışmalara katkı sağlayacaktır. 


\section{Yöntem}

\section{Araştırmanın modeli}

$\mathrm{Bu}$ çalışmada Milli Eğitim Bakanlığı çalışanlarının deneyimlerine ilişkin bir sorgulama yapıldığından araştırma sorularına en uygun cevapların nitel bir çalışmayla alınabileceği varsayılarak bu yönde bir tercihte bulunulmuştur. Patton'a (2014) göre katılımcıların kolaylıkla reddedilecekleri anketlerdeki maddelerin sinir, korku ve endişe ve benzeri duygulara ilişkin derinliği de göz ardı etmekte dolayısıyla ifadelerin görünüş geçerliliği ve inanılırlığını etkilemektedir. Ayrıca bu açıdan da nitel bir çalışma tercih nedeni olmuştur.

Yıldırım ve Şimşek (2013) "nitel bir araştırmada araştırmacının esnek olması, toplanan verilere göre araştırmanın sürecini yeniden biçimlendirmesi ve gerek araştırma deseninin oluşturulmasında gerekse toplanan verilerin analizinde tümevarıma dayalı bir yöntem izlemesi gerektiğini" (s.45) belirtmektedir. Yazarlara göre; "Nitel araştırmanın amacı, bireylerin gerçeği sosyal dünyalarıyla etkileşimleri içinde nasıl inşa ettiği üzerine yoğunlaşmasıdır. Nitel araştırma tekniklerinin doğal ortama duyarlılık sağlaması, araştırmacının katılımcı rolü olması, bütüncül bir yaklaşıma sahip olması, algıların ortaya konmasını sağlaması, araştırma deseninde esnekliği olması ve tümevarımcı bir analize sahip olması önemli özellikleridir” (s. 45).

Türkiye'de günümüze kadar geliştirilen milli eğitim politikalarının Milli Eğitim Bakanlığında görevli yönetici ve uzmanların değerlendirilmesine yönelik olduğundan bu çalışma fenomenolojik bir çalışma olarak desenlenmiştir. Katılımcıların eğitim politikalarının geliştirilmesi sürecine yönelik deneyimlerini sorgulamak bu araştırmanın odağını oluşturmaktadır.

\section{Çalışma grubu}

Çalışmada nitel araştırmalarda kullanılan amaçlı örneklem yönteminden yararlanılmıştır. Merriam'a (1990) göre, “amaçlı örneklem, araştırmacının keşfetmek, anlamak, iç görü kazanmak istediği ve çoğu şeyin öğrenileceği bir örneklem seçiminin zorunlu olduğu varsayımına dayanmaktadır" (s. 47). Balcı (2015) da bu tür örneklemde, örneklem olarak kimlerin seçileceği araştırmacının yargısına bırakıldığını belirtmektedir. Ona göre "böylelikle araştırmacı, araştırmanın amacına en uygun kişileri araştırma sürecine dâhil etmesi mümkün olmaktadır" (s. 99).

Birçok nitel araştırmada örneklem, amaçlı örneklem olarak belirlenmektedir. Burada amaç seçilen örneklemin daha geniş bir örneklemi temsil etmesi değil, kasıtlı olarak seçilen örneklemde konu hakkında daha fazla bilgi toplanabilecek bireylerin olmasıdır (Büyüköztürk ve diğerleri, 2012). Araştırmada maksimum çeşitlilik örneklemesiyle Milli Eğitim Bakanlığında görev yapan şube müdürü, daire başkanı, genel müdür yardımcısı, bakanlık müşaviri ve genel müdürler seçilmiştir.

\section{Katılımcıların demografik özellikleri}

Araştırmaya 2016-2017 eğitim ve öğretim yılında Milli Eğitim Bakanlığında en az 5 yıl süre ile görev yapan şube müdürü, daire başkanı, genel müdür yardımcısı, bakanlık müşaviri ve genel müdürler katılmıştır. Tablo 1'de katılımcıların demografik özellikleri yer almaktadır.

Tablo 1.

Katılımcılarla İlgili Kişisel Bilgiler

\begin{tabular}{|c|c|c|c|c|c|c|c|}
\hline $\begin{array}{l}\text { Sira } \\
\text { No }\end{array}$ & Kodu & $\begin{array}{l}\text { Cinsiy } \\
\text { eti }\end{array}$ & $\begin{array}{l}\text { Mesleki } \\
\text { Kidemi }\end{array}$ & $\begin{array}{l}\text { Mezuniyet } \\
\text { Alanı }\end{array}$ & Görevi & $\begin{array}{c}\text { Bakanlık- } \\
\text { taki Görev } \\
\text { Süresi } \\
\end{array}$ & $\begin{array}{l}\text { Öğretmenlikteki } \\
\text { Görev Süresi }\end{array}$ \\
\hline 1. & E1 & $\mathrm{E}$ & 34 & Sınıf Öğret. & $\begin{array}{l}\text { Bakanlık } \\
\text { Müşaviri }\end{array}$ & 26 & 8 \\
\hline 2. & E2 & $\mathrm{E}$ & 12 & İlahiyat & Şube Müdürü & 7 & 5 \\
\hline 3. & E3 & $\mathrm{E}$ & 31 & Hukuk & Şube Müdürü & 29 & - \\
\hline 4. & $\mathrm{E} 4$ & $\mathrm{E}$ & 31 & İlahiyat & Şube Müdürü & 18 & 13 \\
\hline
\end{tabular}




\begin{tabular}{|c|c|c|c|c|c|c|}
\hline E5 & E & 16 & İlahiyat & Daire Başkanı & 6 & 10 \\
\hline E6 & $\mathrm{E}$ & 22 & İlahiyat & Şube Müdürü & 17 & 5 \\
\hline E7 & $E$ & 13 & İlahiyat & Şube Müdürü & 10 & 3 \\
\hline E8 & E & 33 & $\begin{array}{l}\text { Eğitim } \\
\text { Bilim. }\end{array}$ & Şube Müdürü & 20 & 13 \\
\hline 9. $\quad$ E9 & $\mathrm{E}$ & 33 & Türkçe Öğt. & Şube Müdürü & 22 & 11 \\
\hline 10. E10 & $\mathrm{E}$ & 28 & Eğit. Bilim. & Genel Müdür & 28 & - \\
\hline 11. E11 & $\mathrm{E}$ & 17 & Matem. Öğt. & Şube Müdürü & 5 & 12 \\
\hline 12. E12 & $\mathrm{E}$ & 40 & $\begin{array}{l}\text { Beden Eğt. } \\
\text { Ö. }\end{array}$ & Şube Müdürü & 26 & 14 \\
\hline 13. E13 & $\mathrm{E}$ & 36 & İlahiyat & Gen. Md. Yrd. & 30 & 6 \\
\hline 14. E14 & $\mathrm{E}$ & 32 & İlahiyat & Genel Müdür & 32 & - \\
\hline 15. E15 & $\mathrm{E}$ & 31 & Eğit. Bilim. & Bakan Müşaviri & 12 & 19 \\
\hline 16. E16 & $\mathrm{E}$ & 25 & İlahiyat & Şube Müdürü & 20 & 5 \\
\hline 17. E17 & $\mathrm{E}$ & 21 & Eğit.Bilim. & Şube Müdürü & 13 & 8 \\
\hline 18. $\mathrm{E} 18$ & $\mathrm{E}$ & 35 & $\begin{array}{l}\text { Ticaret ve } \\
\text { Turizm }\end{array}$ & Daire Başkanı & 35 & - \\
\hline 19. E19 & $\mathrm{E}$ & 21 & Sinıf Öğret. & Şube Müdürü & 16 & 5 \\
\hline 20. E20 & $\mathrm{E}$ & 34 & Tarih Öğrt. & Şube Müdürü & 11 & 23 \\
\hline 21. E21 & $\mathrm{E}$ & 37 & $\begin{array}{l}\text { Eğitim } \\
\text { Bilim. }\end{array}$ & Şube Müdürü & 24 & 13 \\
\hline 22. $\mathrm{E} 22$ & $\mathrm{E}$ & 34 & $\begin{array}{l}\text { Türk Dil. ve } \\
\text { Ed. }\end{array}$ & Şube Müdürü & 22 & 12 \\
\hline 23. E23 & $\mathrm{E}$ & 17 & $\begin{array}{l}\text { Türk Dil. ve } \\
\text { Ed. }\end{array}$ & Daire Başkanı & 3 & 14 \\
\hline 24. E24 & $\mathrm{E}$ & 36 & Sınıf Öğrt. & Şube Müdürü & 22 & 14 \\
\hline 25. E25 & $E$ & 17 & Eğt.Bil. & Şube Müdürü & 5 & 12 \\
\hline 26. E26 & E & 20 & İktisat & Genel Müdür & 5 & - \\
\hline 27. E27 & E & 28 & Eğt. Bil. & Genel Müdür & 14 & 14 \\
\hline 28. E28 & $E$ & 21 & İlahiyat & Şube Müdürü & 3 & 17 \\
\hline 29. E29 & E & 35 & Eğit.Bilim. & Daire Başkanı & 23 & 12 \\
\hline 30. E30 & $\mathrm{E}$ & 36 & Kimya Öğrt. & Gen. Md. Yrd. & 30 & 6 \\
\hline $\begin{array}{ll}31 . \quad \text { E31 } \\
\end{array}$ & E & 26 & İlahiyat & Daire Başkanı & 18 & 8 \\
\hline 32. E32 & $\mathrm{E}$ & 28 & Eğit. Bil. & Daire Başkanı & 23 & 5 \\
\hline 33. $\mathrm{K} 1$ & $\mathrm{~K}$ & 14 & İlahiyat & Şube Müdürü & 4 & 10 \\
\hline 34. K2 & $\mathrm{K}$ & 10 & İlahiyat & Şube Müdürü & 6 & 4 \\
\hline 35. E33 & $\mathrm{E}$ & 35 & Eğit.Bil & Daire Başkanı & 28 & 7 \\
\hline 36. E34 & E & 30 & Eğit.Bil. & Şube Müdürü & 22 & 8 \\
\hline 37. E35 & $\mathrm{E}$ & 27 & Eğit.Bil. & Daire Başkanı & 19 & 8 \\
\hline 38. $\mathrm{K} 3$ & $\mathrm{~K}$ & 8 & $\begin{array}{l}\text { DKAB } \\
\text { Öğret. }\end{array}$ & Şube Müdürü & 4 & 4 \\
\hline
\end{tabular}

Tablonun incelenmesinden de anlaşılacağı üzere, 38 katılımcıdan 35'i erkek, 3'ü ise kadındır. Katılımciların görev süresi en az 8, en fazla ise 40 yıl olup ortalamas 130,8 yıldır. Dolayısıyla katılımcıların görevlerinde oldukça deneyimli oldukları söylenebilir.

Mezun oldukları yükseköğrenim alanlarına bakıldığında, katılımcıların ağırlıklı olarak eğitim bilimleri bölümü (12) ile ilahiyat fakültesinden (12) mezun oldukları görülmektedir. Geri kalanı, sınıf öğretmenliği (3), hukuk fakültesi (1), Türkçe öğretmenliği (1), matematik öğretmenliği (1), beden eğitimi öğretmenliği (1), tarih öğretmenliği (1), ticaret ve turizm öğretmenliği (1), Türk dili ve edebiyatı öğretmenliği (2), iktisat fakültesi (1), kimya öğretmenliği (1) ve din kültürü ve ahlak bilgisi öğretmenliği (1) bölümlerinden mezun olmuşlardır. Yine katılımcıların büyük çoğunluğu Milli Eğitim Bakanlığında görev almadan önce öğretmenlik tecrübesine sahiptirler. Bunlardan 18'i 1-10 yıl aras1, 14'ü 11-20 y1l, 1'i 20 y1l üzeri Milli Eğitim Bakanlığına gelmeden önce öğretmenlik yapmış, 5 ' $i$ ise hiç öğretmenlik yapmamıştır. 


\section{Veri toplama aracı ve verilerin toplanması}

Nitel bir araştırma tekniği olarak mülakat, araştırmacı ile katılımcı arasında gerçekleşen bilgi toplama tekniğidir. Mülakat ile gözlem sürecinde, gözlenemeyen birçok olgu hakkında bilgi elde edilebilir (Bogdan ve Biklen, 1998). Hisler, duygular, niyetler ve geçmişte gerçekleşen davranışlar ya da gözlemcinin olmadığı anda gerçekleşen olaylar hakkında gözlem yolu ile bilgi toplanamazken, mülakat ile bu tür konularda bilgi toplanabilir. Daha açık ifade etmek gerekirse, insanların dünyayı nasıl anlamlandırdığını ve onu nasıl örgütlediğini gözlemlerle tespit etmek güçtür, dolayısıyla tecrübeleri öğrenmek için katılımcılara sorular sormak gerekir (Patton, 2014). Görüşmeci, mülakat yöntemi ile katılımcıdan, onun tecrübeleri, hisleri, tavırları, ilgileri, değerleri, düşünceleri hakkında gözleme göre daha etkili veri toplar. Burada iki nokta dikkate alınmalıdır: Mülakat sürecinde anlamın inşası sadece katılımcıya ait değil, beraber oluşturulan bir şeydir. Diğer bir nokta ise katılımcı ve araştırmacı farklı bir kültürel gelenekten geliyorsa veri elde etmekte bir sorun ortaya çıkabilir. İyi mülakat soruları keşfedici, açık uçlu, esnek, yönlendirmesiz bir niteliğe sahip olması gerekir (Marshall ve Rossman, 1999). Bu çalışmada yarı-yapılandırılmış görüşme formu kullanılmıştır. Görüşme formundaki sorular belirli temalar ekseninde örgütlenmiş; kişiyi yönlendiren kısa cevaplı sorular yerine açık uçlu ve katılımcıların daha ayrıntılı konuşmalarına imkân veren sorular hazırlanmıştır. Görüşme formunun kapsam, yap1 ve görünüş geçerliği için 2 eğitim yönetimi alan uzmanının görüşüne sunulmuş ayrıca Milli Eğitim Bakanlığında görev yapan 3 yönetici ile ön görüşme yapılarak onların önerileri doğrultusunda tekrara düşülen bazı sorular yeniden düzenlenerek sorulara son şekli verilmiştir. Çalışmada görüşmecilerin katılımında gönüllülük esasına dayalı olmasına özen gösterilmiştir. Görüşmeler için önceden randevu alınmış ve çalışmanın amacı ile görüşme süreci ve görüşmenin gizliliği hakkında yöneticilere bilgi verilmiştir. Özellikle dijital kayıt için görüşmeciden izin talep edilmiş ve gizlilik konusunda hassasiyet gösterilmiştir. Katılımcılarla görüşme sürecinde görüşme formundaki sorular sorulmuş, yetersiz cevap alındığı durumlarda sonda sorular sorularak katılımcılardan sorularla ilgili ayrıntılı cevaplar alınmaya, böylece katılımcılardan derinlemesine bilgi elde edilmeye çalışılmıştır. Görüşme sürecinde katılımcıların etkilenmemesi için yansız olma, mimik kullanmama vb. hususlara dikkat edilmiştir. Görüşmeler en az 18, en fazla ise 42 dakika sürmüştür. Görüşmeler dijital ortamda kaydedilmiş, bu veriler daha sonra çözümlenmiş ve 80 sayfalık bir metin elde edilmiştir. Çalışmanın dış geçerliliğini sağlamak amacıyla, araştırma yöntemi ayrıntılı olarak açıklanmıştır. Araştırmada görüşlerine başvurulan yöneticilerin kimlik bilgilerini gizli tutmak amacyyla kodlama yapılmıştır. Buna göre, katılımcılardan kadınlara $[\mathrm{K}]$, erkek katılımcılara [E], kısaltması ve her bir katılımcı için bir sayı verilmiştir.

\section{Verilerin analizi}

Wolcott (1994) veri analizinde üç yol önermektedir. Birincisi, toplanan verilerin orijinal formuna mümkün olduğu kadar sadık kalarak ve gerektiğinde araştırmaya katılan bireylerin söylediklerinden doğrudan alıntı yaparak betimsel bir yaklaşımla verileri okuyucuya sunmaktır. İkinci yaklaşım ise, birinci yaklaşımı da içeren bir biçimde, bazı nedensel ve açıklayıcı sonuçlara ulaşmak amacıyla veriler betimsel bir yaklaşımla sunularak ve buna ek olarak bazı temalar ve temalar arası ilişkiler belirlenerek "sistematik analiz" yapmaktır. Üçüncü yaklaşımda ise araştırmacı, birinci veya ikinci yaklaşımı temel alır ve buna ek olarak veri analizi sürecine kendi yorumlarını da dâhil eder (Akt. Yıldırım ve Şimşek, 2013, s. 253). Burada araştırmacının katılımcı ve öznel yönü daha çok ön plana çıkmakta, veri toplamanın yanında veri analizinde, kendi yorumları ve anlayışı ile etkin bir rol üstlenmektedir. Bu araştırmada, ikinci yol kullanılmıştır. Yıldırım ve Şimşek (2013) "nitel araştırmada, veri analizinin çeşitlilik, yaratıcılık ve esneklik anlamına geldiğini, her nitel araştırmanın farklı birtakım özellikler taşıdığını ve veri analizinin birtakım yeni yaklaşımları gerektirdiğini; bu nedenle, araştırmacının var olan veri analiz yöntemlerini de dikkate alarak kendi araştırması için bir veri analiz planı geliştirebileceğini" belirtmektedir (s. 253-254).

$\mathrm{Bu}$ araştırmada elde edilen görüşme kayıtları araştırmacı tarafından deşifre edilerek, bilgisayar ortamında metne dönüştürülmüş ve elde edilen verilerin betimsel analizi araştırmada 
kullanılan görüşme soruları temel alınarak yapılmıştır. Bu amaçla, öncelikle oluşturulan metin birkaç kez okunarak kodlamalar yapılmıştır. Yapılan kodlamalardan yola çıkılarak katılımcıların görüşleri ana ve alt temalara ayrılmıştır. Bunun ardından, anlaş1lırlığı kolaylaştırmak için ana ve alt temalar tablolara yerleştirilmiş ve ortaya çıkan görüşlerin frekans ve yüzdeleri alınmıştır.

\section{Bulgular}

"Türkiye'de eğitim politikaların belirlenmesi ve kamuoyu gündemine gelmesinde etkili olan unsurlar nelerdir?" sorusuna ilişkin katılımcılardan 109 görüş alınmıştır. Katılımcıların verdikleri cevaplara göre bu görüşler "siyaset", "sivil toplum örgütleri (Dernek, vakıf, sendika vb.)", "medya", "cemaat ve tarikatlar", "uluslararası örgütler (AB, OECD, DB, IMF vb.)", "bürokratlar", "toplumsal beklentiler", "teknolojik gelişmeler" ve "üniversiteler" başlıkları altında temalara ayrılmıştır. Elde edilen verilere göre, siyaset teması, "hükümet" ile "ana muhalefet partisi ve TBMM'de grubu olan diğer partiler" alt temalarına; "medya" teması, "gazete ve tv kanalları" ile "sosyal medya" alt temalarına ayrılmış ve sonuçlar Tablo 2'de gösterilmiştir.

Tablo 2.

Türkiye'de Eğitim Politikalarının Belirlenmesi ve Kamuoyu Gündemine Gelmesinde Etkili Olan Unsurlar

\begin{tabular}{llrc}
\hline Tema & Alt Temalar & $f^{*}$ & $\%$ \\
\hline Siyaset & Hükümet & 25 & 22,9 \\
& Ana muhalefet partisi ve TBMM'de grubu olan diğer partiler & 14 & 12,9 \\
& Toplam & 39 & 35,8 \\
\cline { 2 - 4 } & Sivil Toplum Örgütleri (Dernek, vakıf, & 22 & 20,2 \\
sendika vb.) & & \\
\hline Medya & Gazete ve tv kanalları & 12 & 11,0 \\
& Sosyal medya & 2 & 1,8 \\
& Toplam & 14 & 12,8 \\
\hline Cemaat ve tarikatlar & 10 & 9,2 \\
Uluslararasi Örgütler (AB, OECD, DB, IMF vb.) & 10 & 9,2 \\
Bürokratlar & 6 & 5,5 \\
Toplumsal beklentiler & 3 & 2,8 \\
Teknolojik gelişmeler & 3 & 2,8 \\
Üniversiteler & 2 & 1,8 \\
\hline GENEL TOPLAM & 109 & 100 \\
\hline
\end{tabular}

(*) Görüş sıklı̆̆ını göstermektedir.

Tabloda da görüleceği üzere, katılımcılardan 39'u (\%35,8), Türkiye'de eğitim politikaların belirlenmesi ve kamuoyu gündemine gelmesinde siyasetin etkili olduğunu düşünmektedir. Bunlardan 25'i hükümetin (\%22,9), 14'ü ise ana muhalefet partisi ve TBMM'de grubu bulunan diğer partilerin etkili olduğunu $(\% 12,9)$ belirtmiştir. Bu sonuca göre Türkiye'de siyasetin desteklemediği ve benimsemediği eğitim politikalarının gündeme gelmesinin oldukça güç olduğu söylenebilir. Eğitim politikalarının bilimsel yöntemlerle belirlenmesi gerekirken ve bu konuda en etkili unsurun üniversiteler olması beklenirken çok az $(\% 1,8)$ katılımcının, eğitim politikalarının belirlenmesinde ve kamuoyu gündemine gelmesinde üniversitelerin etkili olduğunu belirtmesi oldukça manidardır.

"Belirlenen eğitim politikaları, kamuoyu gündemine geldikten sonra, uygulamaya yönelik kararların alınabilmesi için kimlerle ve hangi çalışmalar yapılmaktadır? sorusuna ilişkin olarak katılımcıların verdikleri cevaplar Tablo 3'te gösterilmiştir. 
Tablo 3.

Belirlenen Eğitim Politikalarının Uygulamaya Geçirilebilmesi için Yapılan Çalışmalar

\begin{tabular}{|c|c|c|c|}
\hline Tema & Alt Temalar & $f^{*}$ & $\%$ \\
\hline \multirow{9}{*}{$\begin{array}{l}\text { Eğitim politikasıyla ilgi çeşitli } \\
\text { kişi, kurum ve kuruluşlardan } \\
\text { görüş̧ alınması }\end{array}$} & $\begin{array}{l}\text { Sivil toplum kuruluşlarından görüş } \\
\text { alınması }\end{array}$ & 11 & 17,5 \\
\hline & Üniversitelerden görüş alınması & 5 & 7,9 \\
\hline & $\begin{array}{l}\text { Bakanlığın ilgili diğer birimlerinden } \\
\text { görüs alınmas } 1\end{array}$ & 4 & 6,3 \\
\hline & $\begin{array}{l}\text { Okul müdürü, öğretmen, öğrenci ve } \\
\text { velilerden görüş alınması }\end{array}$ & 3 & 4,8 \\
\hline & $\begin{array}{l}\text { Eğitim sendikalarından görüş } \\
\text { alınması }\end{array}$ & 2 & 3,2 \\
\hline & $\begin{array}{l}\text { Özel sektör temsilcilerinden görüş } \\
\text { alınması }\end{array}$ & 1 & 1,6 \\
\hline & Siyasi erkten görüş alınmaktadır. & 1 & 1,6 \\
\hline & $\begin{array}{l}\text { Düşünce kuruluşlarından görüş } \\
\text { alınması }\end{array}$ & 1 & 1,6 \\
\hline & Toplam & 28 & 44,4 \\
\hline \multirow{4}{*}{\multicolumn{2}{|c|}{$\begin{array}{l}\text { Eğitim politikasıyla ilgili yasa, yönetmelik, genelge veya yönerge gibi } \\
\text { mevzuat çalışmaları yapılması } \\
\text { Sempozyum ve çalıştay gibi toplantılar yapılması } \\
\text { Eğitim politikasılyla ilgili karar alındıktan sonra herhangi bir çalışma } \\
\text { yapılmaması } \\
\text { Pilot uygulamaların yapılması }\end{array}$}} & 13 & 20,6 \\
\hline & & 13 & 20,6 \\
\hline & & 6 & 9,5 \\
\hline & & 3 & 4,8 \\
\hline \multicolumn{2}{|l|}{ GENEL TOPLAM } & 63 & 100 \\
\hline
\end{tabular}

$(*)$ Görüş sıklı̆ı̆ını göstermektedir.

Tabloda görüleceği gibi katılımcıların 28'i $(\% 44,4)$ belirlenen eğitim politikalarının uygulamaya geçirilebilmesi için eğitim politikasıyla ilgili çeşitli kişi, kurum ve kuruluşlardan görüşler alındığını belirtmiştir. Bunlardan 11'i (\%17,5) sivil toplum kuruluşlarından, 5’i $(\% 7,9)$ üniversitelerden, 4'ü $(\% 6,3)$ Bakanlığın ilgili diğer birimlerinden, 2'si (\%3,2) eğitim sendikalarından, 3’ü $(\% 4,8)$ okul müdürü, öğretmen, öğrenci ve velilerden, 1'i $(\% 1,6)$ özel sektör temsilcilerinden, 1 'i $(\% 1,6)$ siyasi erkten ve 1 'i $(\% 1,6)$ düşünce kuruluşlarından görüş alındığını belirtmiştir. Bu sonuca göre, belirlenen eğitim politikalarının kamuoyu gündemine gelmesinden sonra, Milli Eğitim Bakanlığının uygulamaya yönelik kararların alınmasında demokratik bir yaklaşım gösterdiği söylenebilir.

"Türkiye'de bir eğitim politikasının uygulamaya geçebilmesi için kimler sorumluluk almaktadır?" sorusuna ilişkin olarak katılımcılar 90 görüş belirtmişlerdir. Katılımcıların verdikleri cevaplara göre; "siyaset", "Milli Eğitim Bakanlığı", "sivil toplum örgütleri", "üniversiteler", "ilgili diğer bakanlık ve kuruluşlar" ve "milli eğitim şurası" başlıkları altında 6 tema belirlenmiştir. Ayrıca "siyaset" ana teması altında "parlamento", "hükümet", "bakan"; "Milli Eğitim Bakanlığı" ana teması altında "merkez teşkilatı bürokrasisi", "il, ilçe ve okul yöneticileri", "öğretmenler"; "sivil toplum örgütleri ana temasının altında "sendika ve dernekler" ile "cemaat ve vakıflar" başlıkları altında alt temalar tespit edilmiştir.

Türkiye'de bir eğitim politikasının uygulamaya geçebilmesi için sorumluluk alanlar Tablo 4'te gösterilmiştir.

Tablo 4.

Türkiye'de Bir Eğitim Politikasının Uygulamaya Geçebilmesi İçin Sorumluluk Alanlar

\begin{tabular}{llcl}
\hline Ana Tema & Alt Tema & $f^{*}$ & $\%$ \\
\hline Milli Ĕ̆itim Bakanlığı & Merkez Teşkilatı Bürokrasisi & 35 & 36,4 \\
& İl, ilçe ve okul yöneticileri & 9 & 9,4 \\
& Öğretmenler & 5 & 5,2 \\
\hline
\end{tabular}




\begin{tabular}{llccc} 
& Toplam & 49 & 51,0 \\
\hline Siyaset & Hükümet & 21 & 21,9 \\
& Parlamento & 7 & 7,2 \\
& Bakan & 5 & 5,2 \\
& Toplam & & 33 & 34,3 \\
\hline Sendika ve dernekler & & 5 & 5,2 \\
Cemaat ve tarikatlar & & - & 3 & 3,1 \\
Üniversiteler & & - & 3 & 3,1 \\
İlgili diğer bakanlık ve kuruluşlar & & & 96 & 3,1 \\
\hline GENEL TOPLAM & & & \\
\hline
\end{tabular}

(*) Görüş sıklığını göstermektedir.

Katılımcıların 49'u $(\% 51,0)$ Türkiye'de bir eğitim politikasının uygulamaya geçebilmesi için Milli Eğitim Bakanlığının, 33’ü $(\% 34,3)$ siyasetin, 5’i $(\% 5,2)$ sendika ve derneklerin, 3’ü $(\% 3,1)$ cemaat ve tarikatların, 3’ü $(\% 3,1)$ üniversitelerin 3'ü ise $(\% 3,1)$ ilgili diğer bakanlık ve kuruluşların sorumluluk aldığını belirtmiştir. Eğitim politikalarının belirlenmesinde siyasetin önemli bir rolü olmasına rağmen uygulamaya geçebilmesi için katılımcıların büyük çoğunluğunun da belirttiği üzere sorumluluk Milli Eğitim Bakanlığınındır.

"Türkiye'de bir eğitim politikasının uygulamaya konulabilmesi için hangi koşullar yerine getirilmektedir?" sorusuna ilişkin olarak katılımcılar 64 görüş belirtmişlerdir. Katılımcıların verdikleri cevaplara göre "Herhangi bir hazırlık yapılmadan politikanın uygulanmasına başlanmaktadır.", "Önce politika uygulamaya konulmakta, eksiklikler daha sonra giderilmeye çalışılmaktadır." ve "Uygulamadan önce belirli koşullar yerine getirilmektedir." başlıkları altında 3 tema belirlenmiştir.

Türkiye'de bir eğitim politikasının uygulamaya konulabilmesi için yerine getirilen koşullar Tablo 5'te gösterilmiştir.

Tablo 5 .

Türkiye'de Bir Eğitim Politikasının Uygulamaya Konulabilmesi İçin Yerine Getirilen Koşullar

\begin{tabular}{|c|c|c|c|}
\hline Ana Tema & Alt Tema & $f^{*}$ & $\%$ \\
\hline $\begin{array}{l}\text { Herhangi bir hazırlık yapılmadan } \\
\text { politikanın uygulanmasına bașlanması }\end{array}$ & - & 17 & 26,6 \\
\hline $\begin{array}{l}\text { Politika uygulanarak eksikliklerin daha } \\
\text { sonra giderilmeye çalışılması }\end{array}$ & - & 9 & 14,1 \\
\hline \multirow{10}{*}{$\begin{array}{l}\text { Uygulamadan önce yerine getirilen } \\
\text { koşullar }\end{array}$} & Pilot uygulamalar & 6 & 9,4 \\
\hline & Fiziki kosullar & 6 & 9,4 \\
\hline & Hizmet içi eğitim & 5 & 7,8 \\
\hline & Tanıtım çalışmaları & 4 & 6,3 \\
\hline & Bütçe & 4 & 6,3 \\
\hline & Öğretmen ihtiyacı & 4 & 6,3 \\
\hline & İlgili birimlerin görüşleri & 3 & 4,7 \\
\hline & Mevzuat çalıșmaları & 3 & 4,7 \\
\hline & Yazili talimatlar & 3 & 4,7 \\
\hline & Toplam & 38 & 59,4 \\
\hline GENEL TOPLAM & & 64 & 100 \\
\hline
\end{tabular}

(*) Görüş sıklığını göstermektedir.

Katılımcılardan 38'i $(\% 59,4)$ uygulamadan önce bazı koşulların yerine getirildiğini belirtmişlerdir. Bunlardan 6'sı $(\% 9,4)$ eğitim politikalarının uygulanmasından önce pilot uygulamaların yapıldı̆̆ını, yine 6'sı $(\% 9,4)$ gerekli fiziki koşulların yerine getirildiğini, 5'i $(\% 7,8)$ uygulayıcılara hizmet içi eğitim verildiğini, 4 'ü $(\% 6,3)$ politikanın tanıtım çalışmalarının yapıldığını, 4’ü $(\% 6,3)$ gerekli bütçenin ayrıldığını, 4’ü $(\% 6,3)$ uygulama için öğretmen 
eksikliklerinin giderildiğini, 3'ü $(\% 4,7)$ ilgili birimlerden politikanın uygulanması ile ilgili görüş alındığını, 3'ü $(\% 4,7)$ politikanın uygulanmasından önce mevzuat çalışmalarının yapıldığını, 3’ü $(\% 4,7)$ ise uygulayıcılara yazılı talimatlar gönderildiğini söylemişlerdir.

Diğer yandan katılımcılardan 17'sinin $(\% 26,6)$ herhangi bir hazırlık yapılmadan politikanın uygulandığı görüşünde olması oldukça manidardır. Eğitim politikalarının uygulamaya konulabilmesi için gerekli koşulların yerine getirilmemesi hem zaman hem de ekonomik israfa yol açmaktadır.

"Türkiye'de uygulamaya konulan eğitim politikaları nasıl izlenmektedir?" sorusuna ilişkin olarak katılımcılar 68 görüş bildirmişlerdir. Katılımcıların verdikleri cevaplara göre; "Eğitim politikalarının izlemesi sağlıklı bir şekilde yapılmamaktadır.", "merkez teşkilatınca izleme", "taşra teşkilatınca izleme", "vatandaşlar ve velilerce izleme", "uluslararası kuruluşlarca izleme", "STK ve sendikalarca izleme", "basın ve yayın organlarınca izleme", "üniversitelerce izleme", "eğitim uzmanlarınca izleme" ve "muhalefet partilerince izleme" başlıkları altında yedi ana tema belirlenmiştir.

Türkiye'de uygulamaya konulan eğitim politikaları nasıl izlenmektedir? sorusuna verilen cevaplar Tablo 6' da gösterilmiştir.

Tablo 6.

Türkiye'de Uygulamaya Konulan Eğitim Politikalarını İzleme

\begin{tabular}{|c|c|c|c|}
\hline Tema & Alt Tema & $\mathrm{f}^{*}$ & $\%$ \\
\hline $\begin{array}{l}\text { Eğitim politikaların izlemesinin sağlıklı bir } \\
\text { șekilde yapılmamaktadır. }\end{array}$ & - & 13 & 19,1 \\
\hline \multirow{6}{*}{ Merkez teşkilatınca izleme } & $\begin{array}{l}\text { İzleme ve değerlendirme } \\
\text { birimlerince }\end{array}$ & 17 & 25,0 \\
\hline & $\begin{array}{l}\text { Rehberlik ve Denetim Başkanlığ } 1 \\
\text { elemanlarınca }\end{array}$ & 6 & 8,8 \\
\hline & Talim ve Terbiye Kurulu & 3 & 4,4 \\
\hline & Başkanlığı uzmanlarınca & & \\
\hline & $\begin{array}{l}\text { Strateji Geliştirme Başkanlığı } \\
\text { uzmanlarınca }\end{array}$ & 3 & 4,4 \\
\hline & Toplam & 29 & 42,6 \\
\hline \multirow{5}{*}{ Taşra teşkilatınca izleme } & Okul yöneticileri ve öğretmenlerce & 8 & 11,7 \\
\hline & İl ve ilçe milli eğitim & 1 & 1,4 \\
\hline & müdürlüklerince & & \\
\hline & $\begin{array}{l}\text { Uygulayıcılara ve ögrencilere } \\
\text { uygulanan anketlerle }\end{array}$ & 1 & 1,4 \\
\hline & Toplam & 9 & 14,7 \\
\hline \multirow{4}{*}{ Vatandaşlar ve velilerce izleme } & ALO 147 & 2 & 2,9 \\
\hline & BİMER & 2 & 2,9 \\
\hline & Bilgi Edinme & 2 & 2,9 \\
\hline & Sosyal medya & 1 & 1,4 \\
\hline Toplam & & 7 & 10,2 \\
\hline Sivil toplum örgütlerince izleme & & 4 & 5,8 \\
\hline Uluslararası kuruluşlarca izleme & - & 3 & 4,4 \\
\hline \multirow[t]{2}{*}{ Basın ve yayın organlarınca izleme } & - & 2 & 2,9 \\
\hline & GENEL TOPLAM & 68 & 100 \\
\hline
\end{tabular}

(*) Görüş sıklı̆ı̆ıı göstermektedir.

Katılımcıların 29'una göre $(\% 42,6)$ Türkiye'de uygulamaya konulan eğitim politikaları merkez teşkilatınca izlenmektedir. Bu katılımcılardan 17'si $(\% 25,0)$ izlemenin izleme ve değerlendirme birimlerinin yaptıkları araştırmalarla, 6'sı $(\% 8,8)$ Bakanlığın Rehberlik ve Denetim Başkanlığı elemanlarınca, üçü $(\% 4,4)$ Talim ve Terbiye Kurulu Başkanlığında görevli 
uzmanların raporlarıyla, üçü de $(\% 4,4)$ de eğitim politikalarının Strateji Geliştirme Başkanlığı uzmanlarınca yapıldığını söylemiştir.

Katılımcılardan 13'ünün ise $(\% 19,1)$ Türkiye'de uygulamaya konulan eğitim politikalarının hiç izlenmediğini belirtmesi önemli bir soruna işaret etmektedir.. Bilindiği gibi izleme, politika süreçlerinin en önemli aşamalarından biridir. Uygulamaya konulan politikanın nasıl ilerlediğinin, aksaklıkların ve eksikliklerin tespit edilmesi için sağlıklı bir şekilde izlenmesi gerekmektedir. Aksi takdirde politika sonuçlarının ortaya çıkmasından sonra tespit edilen hataların telafisi mümkün olmayabilir. Bu nedenle hataların zamanında tespit edilmesi, hem zaman hem de para israfina engel olma açısından önemlidir.

"Türkiye'de uygulamaya konulan eğitim politikalarının izlenmesinde ortaya çıkan olumsuzluklara nasıl müdahale edilmektedir?" sorusuna ilişkin olarak katılımcılar 38 görüş bildirmişlerdir. Katılımcıların verdikleri cevaplara göre "Türkiye'de uygulamaya konulan eğitim politikalarının izlenmesinde ortaya çıkan olumsuzluklara müdahale edilmektedir.", "Türkiye'de uygulamaya konulan eğitim politikalarının izlenmesinde ortaya çıkan olumsuzluklara herhangi bir müdahale edilmemektedir." ve "Türkiye'de uygulamaya konulan eğitim politikalarının izlenmesinde ortaya çıkan olumsuzluklara şartlı olarak müdahale edilmektedir." başlıkları altında 3 tema oluşturulmuştur. Türkiye'de uygulamaya konulan eğitim politikalarının izlenmesinde ortaya çıkan olumsuzluklara nasıl müdahale edildiği ile ilgili tema ve alt temalar Tablo 7'de gösterilmiştir.

Tablo 7.

Türkiye'de Uygulamaya Konulan Eğitim Politikalarının İzlenmesinde Ortaya Çıkan Olumsuzluklara Müdahale Etme

\begin{tabular}{|c|c|c|c|}
\hline Tema & Alt Temalar & $f^{*}$ & $\%$ \\
\hline \multirow{6}{*}{$\begin{array}{l}\text { Uygulamaya konulan eğitim } \\
\text { politikalarının izlenmesinde ortaya } \\
\text { çıan olumsuzluklara müdahale } \\
\text { edilmektedir. }\end{array}$} & $\begin{array}{l}\text { Merkezi yönetimce kısmi ve geçici } \\
\text { müdahaleler yapılması }\end{array}$ & 5 & 13,2 \\
\hline & $\begin{array}{l}\text { Politika tamamen yürürlükten kaldırılarak } \\
\text { müdahale edilmesi }\end{array}$ & 4 & 10,5 \\
\hline & $\begin{array}{l}\text { Olumsuzluklara taşraya gönderilen yazılı } \\
\text { talimatlarla müdahale edilmesi }\end{array}$ & 3 & 7,9 \\
\hline & $\begin{array}{l}\text { Olumsuzluklara üst yöneticilerce uygun } \\
\text { görülen müdahaleler yapılması }\end{array}$ & 2 & 5,3 \\
\hline & $\begin{array}{l}\text { Uygulama planlarında ya da içerikte } \\
\text { revizyona gidilerek müdahale edilmesi }\end{array}$ & 1 & 2,6 \\
\hline & Toplam & 15 & 39,4 \\
\hline $\begin{array}{l}\text { Uygulamaya konulan eğitim } \\
\text { politikalarının izlenmesinde ortaya } \\
\text { çıan olumsuzluklara müdahale } \\
\text { edilmemektedir. }\end{array}$ & - & 12 & 31,6 \\
\hline \multirow{7}{*}{$\begin{array}{l}\text { Uygulamaya konulan eğitim } \\
\text { politikalarının izlenmesinde ortaya } \\
\text { çıan olumsuzluklara şartlı olarak } \\
\text { müdahale edilmesi }\end{array}$} & $\begin{array}{l}\text { Olumsuzluklar medya tarafindan kamuoyu } \\
\text { gündemine getirilirse müdahale edilmesi }\end{array}$ & 4 & 10,5 \\
\hline & $\begin{array}{l}\text { Tespit edilen olumsuzluklar bir mevzuat } \\
\text { değisikliği gerektiriyorsa müdahale edilmesi }\end{array}$ & 3 & 7,9 \\
\hline & $\begin{array}{l}\text { Olumsuzluklar ancak siyasilere yansırsa } \\
\text { müdahale edilmesi }\end{array}$ & 2 & 5,3 \\
\hline & $\begin{array}{l}\text { Tespit edilen olumsuzluğun giderilmesi çok } \\
\text { fazla bütçe gerektirmiyorsa müdahale } \\
\text { edilmesi }\end{array}$ & 1 & 2,6 \\
\hline & $\begin{array}{l}\text { Ancak çözümü basit olan olumsuzluklara } \\
\text { müdahale edilmesi }\end{array}$ & 1 & 2,6 \\
\hline & Toplam & 11 & 28,9 \\
\hline & GENEL TOPLAM & 38 & 100 \\
\hline
\end{tabular}

(*) Görüş sıklığını göstermektedir. 
Katılımcıların 15'inin görüşüne $(\% 39,4)$ göre uygulamaya konulan eğitim politikalarının izlenmesinde ortaya çıkan olumsuzluklara müdahale edilmektedir. Bunlardan beşi $(\% 13,2)$ bu müdahalenin merkezi yönetimce kısmi ve geçici müdahaleler şeklinde yapıldığını, dört katılımcı $(\% 10,5)$ eğitim politikalarının izlenmesinde ortaya çıkan olumsuzluklara eğitim politikasının tamamen yürürlükten kaldırılarak müdahale edildiğini, üçü $(\% 7,9)$ uygulanan eğitim politikalarının izlenmesinde ortaya çıkan olumsuzluklara taşraya gönderilen yazılı talimatlarla müdahale edildiğini, 2'si $(\% 5,3)$ ise bu olumsuzluklara üst yöneticilerce uygun görülen müdahalelerin yapıldığını, biri ise $(\% 2,6)$ uygulanan eğitim politikalarının izlenmesinde ortaya çıkan olumsuzluklara uygulama planlarında veya içerikte revizyona gidilerek müdahale edildiğini söylemiştir.

12 katılımcı ise Türkiye'de uygulamaya konulan eğitim politikalarının izlenmesinde ortaya çıkan olumsuzluklara $(\% 31,6)$ herhangi bir müdahalenin yapılmadığını belirtmiştir. Bu olumsuzluklara herhangi bir müdahalenin yapılmadığını belirten katılımcıların sayısı ile eğitim politikalarının izlenmediğini belirtenlerin sayısının birbirine oldukça yakındır. Eğitim politikalarının uygulanmasında ortaya çıkan olumsuzluklara herhangi bir müdahale edilmediği görüşünde olanlar aslında uygulamaya konulan politikaların izlenmediğini belirtmektedirler. Politikaların izlenmesinde ortaya çıkan olumsuzluklara müdahale edilmemesi hem politikanın başarısızlığına neden olacak hem de zaman ve para israfına yol açacaktır.

"Uygulanan eğitim politikaları kimler tarafindan ve nasıl değerlendirilmektedir?" sorusuna ilişkin olarak katılımcılar 76 görüş bildirmişlerdir. Katılımcıların verdikleri cevaplara göre verilen cevaplara göre; uygulanan eğitim politikaları değerlendirilmemektedir." ve "Uygulanan eğitim politikaları değerlendirilmektedir." başlıkları altında iki temaya ayrılmıştır.

"Uygulanan eğitim politikaları kimler tarafından ve nasıl değerlendirilmektedir?" sorusuna verilen cevaplar Tablo 8'de gösterilmiştir.

Tablo 8.

Türkiye'de Uygulanan Eğitim Politikalarını Değerlendirme

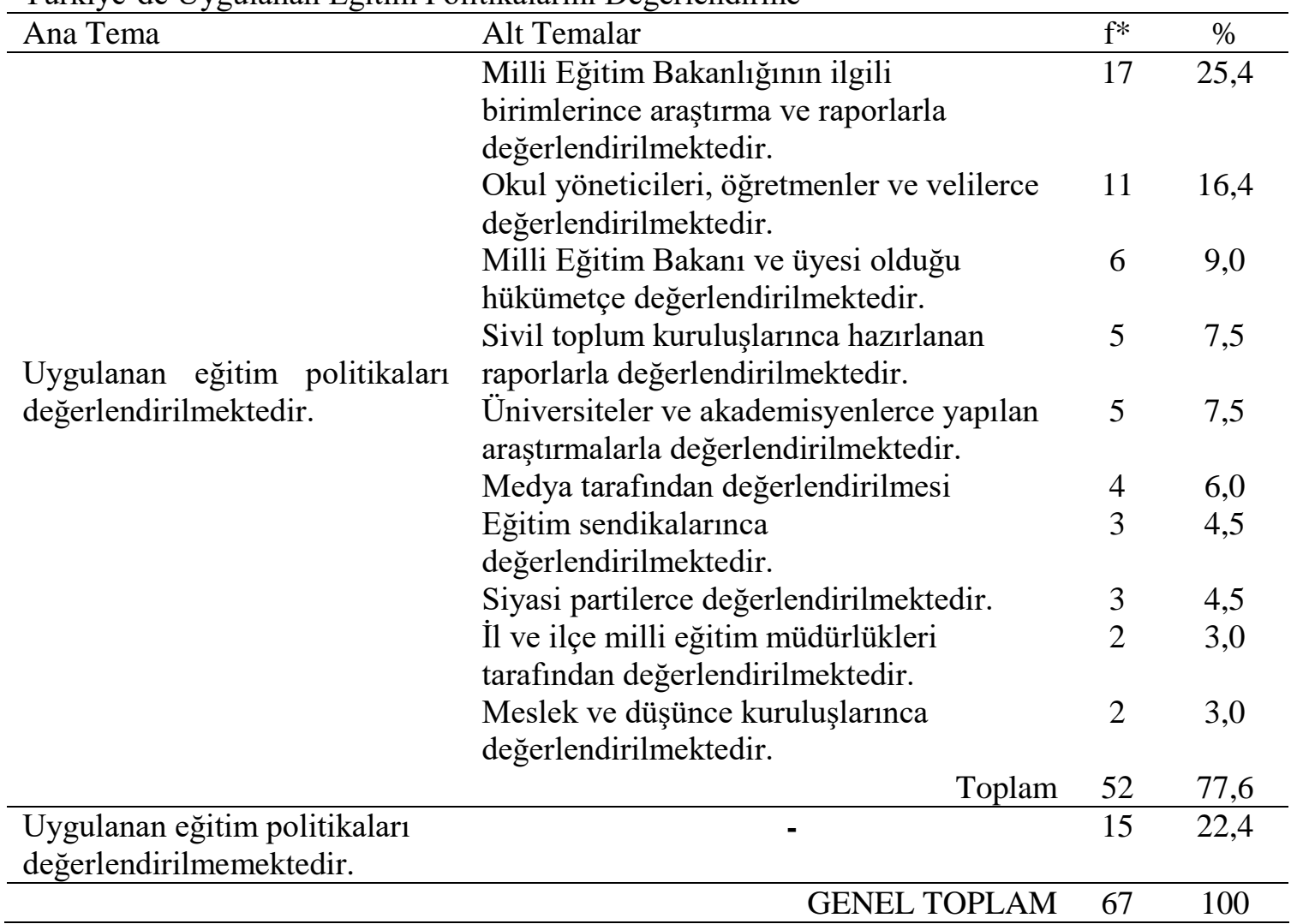

(*) Görüş sıklığını göstermektedir. 
Tabloda görüleceği gibi, 52 katılımcı $(\% 77,6)$ Türkiye'de uygulanan eğitim politikaları değerlendirildiği görüşündedir. Bunlardan on yedi katılımcı görüşüne $(\% 25,4)$ göre uygulanan eğitim politikaları Millî Eğitim Bakanlığının ilgili birimlerince araştırma ve raporlarla, on bir katılımcıya göre $(\% 16,4)$ Türkiye'de uygulanan eğitim politikaları okul yöneticileri, öğretmenler ve velilerce, altı katılımcıya göre $(\% 9,0)$ göre Milli Eğitim Bakanı ve üyesi olduğu hükümetçe, beşine $(\% 7,5)$ göre sivil toplum kuruluşlarınca hazırlanan raporlarla, yine beş katılımcıya $(\% 7,5)$ göre üniversiteler ve akademisyenlerce yapılan araştırmalarla, 4 'üne $(\% 6,0)$ göre medya tarafından, üç katılımcıya göre $(\% 4,5)$ göre eğitim sendikalarınca, yine üç katılımcıya $(\% 4,5)$ göre siyasi partilerce, iki katılımcıya $(\% 3,0)$ göre il ve ilçe milli eğitim müdürlüklerince, 2 katılımcıya $(\% 3,0)$ göre ise meslek ve düşünce kuruluşlarınca değerlendirilmektedir.

On beş $(\% 22,4)$ katılımcı ise "Türkiye'de uygulamaya konulan eğitim politikalarının değerlendirilmediğini" söylemiştir. Uygulamaya konulan eğitim politikalarının izlenmediğini belirten katılımcı sayısı (13 kişi) ile değerlendirilmediğini söyleyen katılımcı sayısının (15 kişi) birbirine oldukça yakın olması anlamlıdır. Bu durumda Türkiye'de eğitim politikalarının izlenmediğini söyleyenlerin aynı zamanda bu politikaların değerlendirilmediğini de belirtmiş̧lerdir. Değerlendirme, politika sürecinin en önemli aşamalarındandır. Uygulamaya konulan bir politikada her zaman beklenen sonuçlara ulaşılamayabilir. Hedeflerde sapmalar olabilir. Değerlendirme aşamasında; istenen hedeflere ne derece ulaşıldığ 1 , sapmaların neler olduğu, politikanın ne derece etkili uygulandığı gibi sorulara cevap aranmaktadır. Türkiye'de uygulamaya konulan eğitim politikalarının değerlendirilmediğini söyleyen katılımcı sayısının yüksek oluşu oldukça düşündürücüdür. Buna göre eğitim politikalarının hedeflerine ulaşılıp ulaşılmadığı, ne gibi sapmaların olduğu, kaynakların yerinde kullanılıp kullanılmadığ belirsizdir. Bunun da ülke kaynaklarının etkili ve verimli kullanılmadığ söylenebilir. "Değerlendirme sonuçlarına göre politikalarda ne gibi değişiklikler yapılmaktadır?" sorusuna verilen cevaplar Tablo 9'da gösterilmiştir.

Tablo 9.

Değerlendirme Sonuçlarına Göre Politikalarda Yapılan Değişiklikler

\begin{tabular}{|c|c|c|}
\hline Tema & $\mathrm{f}^{*}$ & $\%$ \\
\hline $\begin{array}{l}\text { Değerlendirme sonuçlarına göre politikalarda gerekli görülen değişiklikler } \\
\text { yapılmaktadır. }\end{array}$ & 10 & 26,3 \\
\hline $\begin{array}{l}\text { Değerlendirme sonuçlarına göre politikalarda herhangi bir değişiklik } \\
\text { yapılmamaktadır. }\end{array}$ & 9 & 23,6 \\
\hline $\begin{array}{l}\text { Politikalarda değerlendirme sonuçlarına göre değil hükümetin veya Bakanın } \\
\text { değişmesi sonucunda değişiklik yapılmaktadır. }\end{array}$ & 7 & 18,4 \\
\hline $\begin{array}{l}\text { Değerlendirme sonuçlarına göre politikayı revize etmek yerine politikadan } \\
\text { tamamen vazgeçilmektedir. }\end{array}$ & 4 & 10,5 \\
\hline $\begin{array}{l}\text { Değerlendirme sonuçlarına göre değil medyanın sorunları gündeme getirmesi } \\
\text { sonucunda gerekli değişiklikler yapılmaktadır. }\end{array}$ & 2 & 5,2 \\
\hline Değerlendirme sonuçlarına göre mevzuat değişikliği yapılmaktadır. & 2 & 5,2 \\
\hline $\begin{array}{l}\text { Değerlendirme sonucunda sayısal hedeflere ulaşılmadığında değişiklik } \\
\text { yapılmaktadır. }\end{array}$ & 2 & 5,2 \\
\hline $\begin{array}{l}\text { Değerlendirmelerin mantıki ve tarafsılılık gücüne bağlı olarak değerlendirme } \\
\text { sonucunda değişiklik yapılmaktadır. }\end{array}$ & 1 & 2,6 \\
\hline $\begin{array}{l}\text { Değerlendirme sonucuna göre değil kamuoyundan gelen eleştiriler } \\
\text { doğrultusunda politikada gerekli güncellemeler yapılmaktadır. }\end{array}$ & 1 & 2,6 \\
\hline GENEL TOPLAM & 38 & 100 \\
\hline
\end{tabular}

$(*)$ Görüş sıklı̆ıını göstermektedir.

Tabloda görüleceği gibi, "Değerlendirme sonuçlarına göre politikalarda ne gibi değişiklikler yapılmaktadır?" sorusuna ilişkin katılımcılar 38 görüş bildirmişlerdir. Bunlardan 10 'u $(\% 26,3)$ "değerlendirme sonuçlarına göre politikalarda değişikliklerin yapıldığını", dokuzu 
$(\% 23,6)$ "politikalarda herhangi bir değişiklik yapılmadığını", yedisi $(\% 18,4)$ "politikalarda yapılan değişikliklerin değerlendirme sonuçlarına göre değil hükümetin veya Bakanın değişmesi sonucunda yapıldığını", 4’ü $(\% 10,5)$ "değerlendirme sonuçlarına göre politikayı revize etmek yerine politikadan tamamen vazgeçildiğini”, 2'si (\%5,2) "değerlendirme sonuçlarına göre değil, medyanın sorunları gündeme getirmesi sonucunda gerekli değişikliklerin yapıldığını", 2'si $(\% 5,2)$ "politikalarda değişiklik yerine mevzuat değişikliğine gidildiğini”, 2 'si $(\% 5,2)$ "sayısal hedeflere ulaşılmadığında değişiklik yapıldığını", biri $(\% 2,6)$ "değişikliklerin yapılmasının değerlendirmelerin mantıki ve tarafsızlık gücüne bağlı olduğunu" ve biri de $(\% 2,6)$ "uygulamaya konulan politikayla ilgili değerlendirme sonucuna göre değil kamuoyundan gelen eleştiriler doğrultusunda gerekli güncellemelerin yapıldığını" belirtmiştir.

Değerlendirme sonuçlarına göre politikalarda gerekli görülen değişikliklerin yapıldığını belirten katılımcı sayısı (10 kişi) ile değerlendirme sonuçlarına göre herhangi bir değişikliğin yapılmadığını belirten katılımcıların sayısının (9 kişi) birbirine oldukça yakın olması dikkate değerdir. $\mathrm{Bu}$ oran, katılımcıların Türkiye'de uygulamaya konulan eğitim politikalarının değerlendirmesi sonucuna göre politikalarda değişiklik yapılıp yapılmadığ konusunda net bir fikre sahip olmadıklarını göstermektedir.

\section{Sonuç, Tartışma ve Öneriler}

\section{Sonuç ve Tartışma}

Araştırma sonucuna göre Türkiye'de eğitim politikaların belirlenmesi ve kamuoyu gündemine gelmesinde en etkili olan unsur siyaset, en az etkisi olan unsur ise üniversitelerdir.

Türkiye'de eğitim ve siyaset daima iç içe olmuştur. 1923'ten itibaren eğitim, devlet ideolojisinin ve siyasetinin başat kurumu olarak konumlandırılmışır ve siyaset daima eğitimle ilgilenmiştir. Türkiye siyasi tarihine bakıldığında etkili olan siyasi düşünce, eğitimi yönlendirmiş ve siyasi partiler toplumu kendi ideolojileri doğrultusunda şekillendirmeye çalışmışlardır. Eğitim politikalarının sıklıkla değişmesinin nedeni de bu olmaktadır (Ilkaya, 2016). Yapılan bir araştırma da Türkiye'deki eğitim politikası oluşturma sürecinin politik, tepeden inme, hükümet merkezli olduğunu göstermektedir (Aschenberger, 2012). Diğer yandan Türkiye'de eğitim politikalarının belirlenmesi ve kamuoyu gündemine gelmesinde etkisi en az olan unsurun üniversiteler olması oldukça düşündürücüdür ve eğitim politikası konusunda Türkiye'deki üniversitelerin işlevi hakkında da bilgi vermektedir. Üniversitelerin görevi dünyaya geniş açıdan bakan, özgür düşünen ve düşüncelerini serbestçe ifade edebilen insan yetiştirmektir. Amaç üst düzeyde öğretim ve araştırma yaptırarak, topluma bilimsel düşünme yeteneği ve becerisine sahip bireyler hazırlamaktır (Baran ve Kahraman 2004). Bir başka deyişle, üniversite; özgür düşünceyle doğrunun arandığ 1 , soru sormanın, tartışma yapmanın öğretildiği, aklın dogmaya üstünlüğünün kanıtlandığı ve topluma bu doğrultuda katkıda bulunacak sorumluluk bilincine sahip bireyler yetiştirmenin hedeflendiği bir yapıdır (Gökçe, 1990). Bunun yanında üniversiteler fikirlerin üretildiği ve özgürce tartışıldığ 1 eğitim kurumlarıdır. Üniversiteler aynı zamanda bilimsel araştırma ve geliştirme faaliyetlerinin yapıldığı yerlerdir. Türkiye'de eğitim problemlerinin objektif olarak belirlenmesinde ve gündeme gelmesinde üniversitelere önemli görevler düşmektedir. Eğitim problemleri kişilere veya toplumun değişik kesimlerine göre farklı öneme sahip olabilir. Bu nedenle problemlerin bilimsel araştırmalarla tespit edilmesi oldukça önemlidir. $\mathrm{Bu}$ görev de üniversitelere düşmektedir. Milli Eğitim Bakanlığı bu konuda üniversitelerden daha fazla yararlanmalı ve politikalarını bilimsel araştırmalarla belirlenen problemlere göre geliştirmelidir. Ancak araştırma sonucuna eğitim problemlerinin belirlenip kamuoyu gündemine gelmesinde üniversitelerin etkisi yok denecek kadar azdır. Bu durum, Türkiye'de eğitim problemlerinin belirlenmesinde ve kamuoyu gündemine gelmesinde bilimsellikten uzak bir yaklaşım izlendiğini ortaya koymaktadır.

Katılımcıların çoğunluğuna göre belirlenen eğitim politikalarının uygulanmasına yönelik kararların alınabilmesi için eğitim politikasıyla ilgi çeşitli kişi, kurum ve kuruluşlardan görüşler alınmaktadır. Bunlar sivil toplum kuruluşları, üniversiteler, bakanlığın ilgili diğer 
birimleri, okul müdürü, öğretmen, öğrenci ve veliler, eğitim sendikaları, özel sektör temsilcileri, siyasi erk ve düşünce kuruluşlarıdır. Eğitim politikalarının uygulanmasından birinci derecede sorumlu olan Milli Eğitim Bakanlığıdır. Milli Eğitim Bakanlığı, katılımcıların da belirttiği üzere politikanın muhatabı paydaşlardan görüş alarak kararlarına zemin oluşturmaktadır. Burada dikkat çeken önemli husus en fazla STK'lardan görüş alındığının belirtilmesidir. STK'lar son dönemde eğitim politikaları ile insan yetiştirme düzeni konusunda gittikçe etkileri artan, katkıları ve belirleyicilikleri oranında da önem arz etmeye başlayan kurumlar arasında önemli yere sahiptir. STK'ların kamu politikalarındaki rolüne ilişkin olarak Bovard (2003) "politikalar belirlenirken ve uygulanırken, eğitimciler bu uygulamaların dışında kalamayacağı için ülkedeki eğitim politika ve uygulamaların da onların irade, istek ve beklentilerini dikkate almak gerektiğini" söylemektedir (Akt. Asri, 2015, s. 90). Ancak yapılan bir araştırma, Türkiye'de eğitim alanındaki sivil toplum örgütlerinin oldukça güçsüz ve yetersiz olduğunu göstermektedir. Bunun en önemli nedeni devletin sivil toplum örgütlerine yeterli hareket alanı birakmaması olarak gösterilmektedir (Aschenberger, 2012).

Eğitim politikalarının uygulanmasından önce siyasi desteğin sağlanması da son derece önemlidir. Siyaset tarafından desteklenmeyen politikaların başarılı olması mümkün görülmemektedir. Kaptı'ya (2011) göre "herhangi bir politikayla ilgili siyasi desteğin yüksek olması halk desteğini de etkilemektedir. Gerek siyasi çevreden gerekse halk tarafından çekince bulunan ve uygulanmanın istenmediği durumlarda uygulamada verim düşmektedir. Her iki desteğin var olması ise uygulama sürecini olumlu yönde etkilemektedir" (s. 34).

Araştırma sonucunda dikkat çeken bir başka nokta, çok az sayıda katılımcının eğitim politikalarının uygulanmasından önce pilot uygulamaların yapıldığını ifade etmesidir. Oysa bir politikanın uygulanmasından önce politikanın aksayan yönlerini görme açısından pilot uygulamanın yapılması çok önemlidir. Pilot uygulamalar, politikanın süreci hakkında politika yapıcılara bir fikir vermekte ve politikanın genel uygulamasından önce aksayan yönlerinin görülmesini sağlamaktadır. Bu da zaman ve para israfını önleme açısından önem arz etmektedir. Araştırma sonucuna göre, Türkiye' de bir eğitim politikasının uygulamaya geçebilmesi için Milli Eğitim Bakanlığı sorumluluk almaktadır. Milli Eğitim Bakanlığı ana teması altında bu sorumluluğu merkez teşkilatı ve bürokrasisi, il, ilçe ve okul yöneticileri ve öğretmenler paylaşmaktadır.

Türk eğitim sistemi merkezi bir yapıya sahiptir. Eğitim politikalarının belirlenmesinde siyasi aktörler, hükümet, STK'lar, medya vb. aktörler etkili olsa da uygulama aşamasında sorumluluk Milli Eğitim Bakanlığına aittir. Çünkü politikaya son şeklini veren, uygulama ile ilgili yasal mevzuatı hazırlayan ve politikanın takibini yapan Milli Eğitim Bakanlığıdır. Bu aşamada milli eğitim bürokrasisi önemli bir rol oynamaktadır. Politika tasarımlarının yapılması, gerekli durumlarda yasal mevzuatının alt yapısının oluşturulması, uygulama ile ilgili yol haritasının düzenlenmesi vb. çalışmalar merkez teşkilatı bürokrasisince gerçekleştirilmektedir.

Araştırma sonucuna göre Türkiye'de bir eğitim politikasının uygulamaya konulabilmesi için pilot uygulamalar, fiziki koşullar, hizmet içi eğitim, politikayı tanıtım çalışmaları, gerekli bütçenin ayrılması, öğretmen ihtiyacının karşılanması, ilgili birimlerin görüşlerinin alınması, gerekli mevzuat çalışmalarının yapılması ve uygulayıcılara yazılı talimatlar gönderilmesi gibi koşullar yerine getirilmektedir. Diğer taraftan Türkiye' de eğitim politikalarının herhangi bir hazırlık yapılmadan uygulandığını belirten katılımcı sayısı ise azımsanmayacak düzeydedir.

Eğitim politikası sürecinin en önemli basamağı uygulama aşamasıdır. Bir eğitim politikası ne kadar mükemmel formüle edilirse edilsin uygulama aşamasındaki aksaklıklar onun başarısını olumsuz etkileyecektir. Başka bir deyişle eğitim politikasının başarısı uygulama başarısına bağlıdır. Fitz ve diğerleri (1994) politika uygulama sürecini "politika hedeflerinin eyleme dönüştürülmesi safhası" (Akt. Kaptı, 2011, s. 33) olarak tanımlamaktadır. Aypay'a (2015) göre "uygulamanın başarıya ulaşması için uygulama öncesi (ex-ante) ve uygulama sonrası (ex-post) analiz önem arz etmektedir. Uygulama öncesi analiz önerilen çözüme yönelik olarak hangi sorunların ortaya çıkabileceği ve bu sorunların nasıl ortadan kaldırılabileceğine yönelik analizdir. Bu tür bir analiz, politika analiz süreçlerinin her aşamasının incelenmesi ve geçmişte kullanılan çözümler dışında başka seçeneklerin olup olmadığının incelenmesini de 
gerektirir" (s. 263). 6 katılımcının belirttiği üzere Türkiye'de bazı politikaların uygulama öncesi pilot uygulamaları yapılmaktadır. Eğitim politikalarının uygulanmasından önceki pilot uygulamalar uygulama öncesi analizler için iyi bir firsat sunar. Ancak Türkiye'de bugüne kadar yapılan uygulamalara bakıldığında pilot uygulamalarda ortaya çıkan aksaklıkların düzeltilmesi yerine, bu aksaklıklar göz ardı edilerek uygulamaları başarılı gösterme çabalarının ağırlık kazandığı görülecektir.

Aypay (2015) uygulama sonrası (ex-post) analizlerin uygulamanın tamamlanmasından sonra daha önce verilen kararların izlenmesi ve değerlendirilmesiyle ilgili olduğunu söylemektedir. Bir politikanın uygulanmasından sonra politikayla ilgili öğretmen, veli ve okul yöneticilerinden dönüt alınması bu analize örnek olarak gösterilebilir. Türkiye'de genellikle sayısal veriler alınmakta ve sayısal olarak beklenen hedeflere ulaşılıp ulaşılmadığ değerlendirilmektedir. Ancak değiştirilen bir öğretim programının başarısının ölçülmesi veya öğretmen politikalarının değerlendirilmesi gibi nitel analizlerin sistemli olarak yapıldığını söylemek güçtür.

Araştırmaya göre Türkiye'de uygulamaya konulan eğitim politikaları merkez teşkilatınca izlenmektedir. Bu izleme ise;

- İzleme ve değerlendirme birimlerince,

- Milli Eğitim Bakanlığı Rehberlik ve Denetim Başkanlığınca,

- Talim ve Terbiye Kurulu Başkanlığı uzmanlarınca ve

yapılmaktadır.

- Strateji Geliştirme Başkanlığı uzmanlarınca

Katılımcıların azımsanmayacak bir oranı da (13 kişi) Türkiye'de uygulamaya konulan eğitim politikalarının izlenmesi sağlıklı bir şekilde yapılmadığını belirtmiştir. Siyasi istikrarsızlıklar nedeniyle bakanların ve buna bağlı olarak bürokratların sürekli olarak değiştirilmesi, Türkiye'de uygulanan eğitim politikalarının da sağlıklı bir şekilde izlenmesini engellemektedir. Daha doğrusu sürekli değiştirilen bakan ve bürokratlarla birlikte eğitim politikaları da değişmektedir. $\mathrm{Bu}$ da uygulamadaki eğitim politikalarının izlenip değerlendirilmesi ve buna göre değişikliklerin yapılması yerine politikaların tümden kaldırılmasını ve yeni politikaların belirlenip uygulanmasını beraberinde getirmektedir.

Araştırmaya katılan katılımcıların Türkiye'de uygulamaya konulan eğitim politikalarıyla ilgili olarak ortaya çıkan olumsuzluklara müdahale edilmediğini söyleyenlerle müdahale edildiğini ve şartlı olarak müdahale edildiğini söyleyenlerin sayıları birbirine yakındır. Bu sonuçlara bakıldığında Türkiye'de uygulamaya konulan eğitim politikalarının izlenmesinde ortaya çıkan olumsuzluklara müdahale etme konusunda katılımcıların net bir görüşe sahip olmadıklarını söylemek mümkündür.

Gerek zaman gerekse para israfını önlemek açısından uygulamaya konulan eğitim politikalarının izlenmesi ve izleme sonucunda ortaya çıkan olumsuzluklara gerekli müdahalelerin yapılması önemlidir. $\mathrm{Bu}$, bazen politikanın hedeflerinin anlaşılması ile ilgiliyse yazılı talimatlarla olabilmekte, bazen de politikalarda kısmi müdahalelerin yapılmasını zorunlu kılabilmektedir. Zamanında müdahale edilmeyen olumsuzluklar sonraki zamanlarda telafisi mümkün olmayan daha büyük olumsuzlukları doğurabilir.

Araştırma sonucuna göre büyük oranda Türkiye'de uygulanan eğitim politikaları değerlendirilmektedir. Eğitim politikalarının değerlendirilmesi; Milli Eğitim Bakanlığının ilgili birimlerinin yaptığı araştırmalarla ve bu konuda düzenlenen raporlarla; okul yöneticileri, öğretmenler ve velilerce; Milli Eğitim Bakanı ve üyesi olduğu hükümetçe; sivil toplum kuruluşlarınca hazırlanan raporlarla; üniversiteler ve akademisyenlerce yapılan araştırmalarla; medya tarafından; eğitim sendikalarınca; siyasi partilerce; il ve ilçe milli eğitim müdürlükleri tarafından; meslek ve düşünce kuruluşlarınca yapılmaktadır.

Çevik ve Demirci'ye (2012) göre değerlendirme, "uygulanan bir eğitim politikasının etkinliğinin belirlenmesi ve hedeflerine ulaşılıp ulaşılmadığının saptanması" (s. 63) şeklinde tanımlanabilir. Değerlendirme aşaması politika sürecinin en önemli aşamasıdır denilebilir Başka bir deyişle değerlendirme eğitim politikasının sonucu hakkında bilgi edinmektir. Burada iki 
değerlendirme türünden söz edilebilir: Birincisi süreç değerlendirmesi, ikincisi ise sonuç değerlendirilmesidir. Süreç değerlendirmesi eğitim politikasının formüle aşamasındaki belirlenen hedefleri doğrultusunda ilerleyip ilerlemediğinin tespit edilmesi, bir bakıma izlenmesidir. Sonuç değerlendirmesi ise eğitim politikasının uygulanması sonucunda politikadan beklenen amaçların gerçekleşip gerçekleşmediği hakkında bilgi edinmektir.

Değerlendirme sonucuna göre politikalarda değişiklik yapıldığını söyleyenlerin oranı ile değerlendirme sonuçlarına göre politikalarda herhangi bir değişikliğin yapılmadığını söyleyenlerin sayısının birbirine oldukça yakın olması bu konuda katılımcıların net bir görüşe sahip olmadıklarını göstermektedir. Hall (2011) eğitim politikası yapmanın sadece kanun metinlerinin veya diğer mevzuatın yazılması ve uygulanmasından ibaret olmadığını, politika sürecinin asıl bu aşamadan sonra istenen hedeflere ulaşılıp ulaşılmadığı, uygulama sonuçlarının neler olduğu ve başka bir değişime ihtiyaç olup olmadığı gibi sorulara da cevap aradığını söylemiş̧ir (Akt. Çevik ve Demirci, 2012, s. 18). Uygulanan politikalar değerlendirmeye göre ya devam ettirilir, ya gerekli düzeltme ve düzenlemeler yapılır ya da sonlandırılır. Ancak Türkiye'deki eğitim uygulamalarına bakıldığında, politikalardaki değişikliklerin veya politika sonlandırmasının değerlendirme sonuçlarına göre değil Bakanların veya bürokratların değişmesi sonucunda ve siyasi etkilere göre yapıldığı görülmektedir.

\section{Öneriler}

Günümüzde gelişmiş ülkeler sadece bilim ve teknolojiyi kullanan değil, aynı zamanda üreten ülkelerdir. $\mathrm{Bu}$ nedenle ülke olarak artık bilimsel ve teknolojik değişmelere sadece ayak uydurmakla kalmayıp toplum olarak üretilen bilgilere başka ülkelerin ayak uydurmasına neden olacak değişim ve gelişmeleri hedeflemek gerekmektedir. Bunun için öncelikle ulusal bir eğitim politikasına ihtiyaç duyulmaktadır. Ulusal bir eğitim politikasını belirlemek ise bir eğitim felsefesi temeline dayanır. Eğitim felsefesi için siyasal sistemler bir araçtır. Ancak siyasal sistem eğitim felsefesine yön verecek olursa eğitim politikalarını belirlemek güçleşecek ve sürekli değiştirilebilir hale getirecektir. Bununla birlikte eğitim politikalarının belirlenmesi ve uygulanmasında en önemli argüman bilimsel bilgidir. Belirlenen eğitim politikaları güncel ve geliştirilebilir bir bilim anlayışı ile desteklenmediği sürece, soyut ve ütopik bir taslak olmaktan öteye gidemezler. Siyasal sistemler eğitim yoluyla belirli bir ideolojiye uygun bireyler yetiştirmek yerine; her türlü düşünceye saygıyla ve eleştirel bakabilen, vizyon sahibi, demokratik ve hoşgörülü bireyler yetiştirecek eğitim politikaları belirlemelidir.

Bu bağlamda;

1. Siyasal ve sosyal sistemler ile bu sistemdeki dinamiklerin işbirliğiyle ve eğitim politikalarının belirlenmesinde ön koşulun eğitim sisteminin genel amaçları kapsamında öncelikle ulusal bir eğitim politikası belirlenmelidir.

2. Eğitim politikalarının belirlenmesinde çoğulcu bir demokratik anlayışıyla, toplumda yaşayan farklı düşünceleri dikkate alarak meslek odaları, sivil toplum örgütleri, düşünce kuruluşları ve eğitim sendikalarının görüşleri dikkate alınmalıdır.

3. Üniversiteler bir ülkenin bilim üreten örgütleridir. Her bir eğitim alt sistemi ve genel anlamda eğitim sistemine yönelik alınacak kararlar, belirlenecek politikalar ve bu politikaların izlenmesi ve sürdürülmesinde üniversiteler, Milli Eğitim Bakanlığının en önemli destekçisi olmalıdır. Bu nedenle politika analizlerinde, politika belirleme ve değerlendirme süreçlerinde, eğitim alanında öncü eğitim fakülteleri ile işbirliği yapilmalidir.

4. Uygulamaya konulan eğitim politikaları başlangıcından sonuçlanıncaya kadar bilimsel yöntemlerle izlenmeli ve uygulama aşamasında ortaya çıkan olumsuzluklara gerekli müdahaleler anında yapılmalıdır.

5. Eğitim politikalarının belirlenebilmesi ve analizinde karar vericilere önemli dönütler verecek bir unsur ise eğitim verileridir. Eğitim politikalarının değerlendirilmesinde kullanılacak eğitim verilerinin Milli Eğitim Bakanlığınca üniversitelerle paylaşılması, eğitim akademisyenlerinin politika analizi ve değerlendirmelerine önemli katkı sağlayacaktır. 
6. Eğitim politikalarının belirlenmesi ve değerlendirilmesinde, bu politikalardan en çok etkilenen ve bu politikaların uygulama sorumlusu olan öğretmen ve okul yöneticilerinin karar verme sürecine katılmaları, politikaların uygulanabilirliğini artıracaktır.

\section{Kaynaklar}

Adem, M. (1995). Demokratik, laik, çağdaş eğitim politikası. Ankara: Şafak.

Aschenberger, F. K. (2012). Dynamics of policy formation in Turkey and the U.S.A comparative case study of two reform initiatives (Yayımlanmamış doktora tezi). Ortadoğu Teknik Üniversitesi Sosyal Bilimler Enstitüsü, Ankara.

Asri, S. (2015). Türkiye'de eğitim politikalarının aktörleri. A. Gümüş (Yay. haz.). Türkiye'de eğitim politikaları, içinde (ss. 77-109). Ankara: Nobel.

Aypay, A. (2015). Ĕgitim politikası. Ankara: Pegem A.

Balc1, A. (2015). Sosyal bilimlerde araştırma yöntem, teknik ve ilkeler (11. Baskı) Ankara: Pegem A.

Baran, T. ve Kahraman, S. (2004). Mühendislik eğitiminde probleme dayalı öğrenme modelleri. Mühendislik Dekanları Konseyi, I. Ulusal Mühendislik Kongresi, içinde (ss. 31-40). İzmir.

Bogdan, R. C. ve Biklen, S. K. (1998). Qualitative research for education an indroduction to theory and methots. Boston: Allyn and Bacon.

Bovard, A. (2003). Politikaları etkileme süreçlerinde sivil toplum kuruluşlarının rolü. Bilgi Üniversitesi, Sivil Toplum Kuruluşları Eğitim ve Araştırma Birimi. STK Yönetimi

Konferans Yazıları, 2. Erişim adresi: stk.bilgi.edu.tr/media/uploads/2015/01/31/ bovard_stk_2. Pdf

Büyüköztürk, Ş., Çakmak, E. K. Akgün, Ö. E., Karadeniz, Ş. ve Demirel, F. (2012). Bilimsel araştırma yöntemleri (Onüçüncü Baskl). Ankara: Pegem A.

Çevik, H. H. ve Demirci, S. (2012). Kamu politikası: Kavramlar, aktörler, süreç, modeller, analiz, karar verme (2. Bask1). Ankara: Seçkin.

Çevik, H. H. (2013). Gelişmiş ülkelerde ve Türkiye'de kamu politikası başarısızlığı. M. Yıdız ve M. Z. Sobacı (Yay. haz.) Kamu Politikası Kuram ve Uygulama. (ss. 266-286). Ankara: Adres.

Gökçe, B. (1990). Türkiye koşullarında yeni bir üniversite nasıl kurulmalı? Üniversite Öğretim Üyeleri Derneği. Yükseköğretimde Sorunlar ve Çözümler, içinde (ss. 91-108). İstanbul: Cem.

Gür, B. (2011). Eğitim politikalarının izlenmesi ve değerlendirilmesi. 21. Yüzyılda Türkiye'nin Eğitim ve Bilim Politikaları Sempozyumu Bildiriler, içinde (s.223-231). Eğitim-Bir Sen, Ankara.

Hansen, W. (2008). 80. Yll Uluslararası eğitim formu: Ĕgitim hakkı ve gelecek perspektifleri. G. Özdemir (Yay. haz.). TED, Ankara.

Hoşgörür, V. (2005). Ekonomik ve sosyal kalkınmada eğitim. Yüzüncü Yıl Üniversitesi Eğitim Fakültesi Dergisi, 1-11.

İlkaya, M. A. (2016). Eğitim ve siyaset. Erişim adresi: www.hurfikirler.com/egitim-ve-siyaset/

Kaptı, A. (2011). Kamu politika sürecinde klasik yaklaşım modeli. A. Kaptı (Yay. haz.). Kamu Politika Süreci, Teorik Perspektifler içinde (ss. 23-45). Ankara: Seçkin.

Kavak, Y. (2010). 2050’ye doğru nüfusbilim ve yönetim: Eğitim sistemine bakış. Ankara: TÜSİAD.

Kaya, Y. K. (1995). Kalkınmada eğitimin rolü. ABC Dergisi, 102, 26-28.

Marshall, C. ve Rossman, G. B. (1999). Designing qualitative research (3rd ed.). London: Sage Publications.

Merriam, S. B. (1990). Case study research in education. San Francisco: Jossey-Bass.

Patton, M. Q. (2014). Nitel araştırma ve değerlendirme yöntemleri. M. Bütün ve S. B. Demir (Çev.). Ankara: Pegem A.

Sarı, S. (2015). Türkiye'de eğitim politikalarının aktörleri. A. Gümüş (Yay. haz.). Türkiye'de eğitim politikaları içinde (ss. 77-109). Ankara: Nobel. 
Sezgin, İ. (2001). 2000 yılında Türk milli eğitimi ve yönetimi ulusal sempozyumu (Aç1lış konuşmas1). Ankara: Öğretmen Hüseyin Hüsnü Tekışık Eğitim, Araştırma, Geliştirme Vakfi.

Wigley, S. ve Akkoyunlu, A. (2013). Türkiye'de eğitim politikalarının gelişimi ve sonuçları. M. Yıldız ve M. Z. Sobacı (Yay. haz.). Kamu politikası, kuram ve uygulama (1. Baskı). Ankara: Adres.

Yıldırım, A. ve Şimşek, H. (2013). Sosyal bilimlerde nitel araştırma yöntemleri (9. Genişletilmiş Baskı). Ankara: Seçkin.

\section{Extended Abstract}

\section{Introduction}

There is a direct relationship between education level of countries and development level. For this reason, countries care more to education in order to train the manpower they need and improve their competitiveness with other countries. Because the development of a country depends on having qualified manpower. Hoşgörür (2005) draws attention to the importance of education on this issue and emphasizes that education is an important tool that prepares trained manpower. Both developed and developing countries see education as an important factor in the development of the country. Because trainning qualified people depends on education.

Gur (2011) says that the national education system so far in Turkey was considered as a holistic system, so changes made within the system was put into effect without analyzing enough impact on other elements of the system. In fact, there is no consensus on education policy which is in Turkey. The frequent changes of the ministers of education in recent years are an indication of this. The change is not only the ministers but also the education policies with the ministers. Therefore, the desired goals cannot be achieved in the education system. When the practices in the Turkish Education System are examined from the past to the present, it can be said that there are some problems related to the quality of educational policies.

\section{Method}

This study is based on the experience of Ministry of National Education employees. Assuming that the most appropriate answers to the research questions can be obtained by a qualitative study, a preference has been made in this direction. This study was designed as a phenomenological study because the national education policy in Turkey developed by has been subjected to the present evaluation of the executives and specialists. The focus of this research is interrogating the participants' experiences in the development of educational policies.

\section{Participants}

In this study, purposive sampling method for qualitative research was used. The purposive sample is based on the assumption that the researcher is encouraged to choose a sample in which he wants to discover, understand, insight and learn most things (Merriam, 1990, p. 47). In order to reach maximum diversity sampling for the study, 38 people amoung branch managers, department head, assistant general managers, ministry consultants and general managers working in the ministry of National Education have been selected. 35 of them are male and 3 are female.

\section{Data collection}

The data were collected through a semi-structured interview form. An appointment was made in advance of the interviews and the participants were informed about the purpose of the study, the interview process and the confidentiality of the interview. During the interview process, the participants were asked questions and detailed answers were received. The interviews were recorded and the data were then analyzed. In order to keep the confidentiality of the participants' credentials, they are coded. Accordingly, women [K], men [E] are shown with the abbreviation and numbers have been given for each participant. 


\section{Data analysis}

The interview records obtained in this research were deciphered by the researcher and converted into text in computer environment. Data was evaluated using descriptive analysis. For this purpose, firstly the generated text was read several times and coded by following interwiew questions. After the coding, participants' opinions were divided into main and sub themes. Frequency and percentages of main and sub-themes are interpreted.

\section{Conclusion, Discussion and Suggestions}

In determining the Turkish education policies and to bring them to the public agenda, the most influential element is politics, and the least influential element is universities. In Turkey education and politics has been always intertwined. The fact that universities in Turkey have little impact on determination of educational policies and bringing them to the public agenda shows us the function of the universities in Turkey.

According to the majority of the participants, opinions are taken from various individuals, institutions and organizations interested in educational policy in order to make decisions about the implementation of the determined educational policies. These are nongovernmental organizations, universities, other relevant departments of the ministry, school principals, teachers, students and parents, education unions, private sector representatives, political institutions and think tanks. It is the Ministry of National Education which is primarily responsible for the implementation of educational policies. As the participants stated, the Ministry of National Education makes its decisions by taking opinions from stakeholders.

Another striking point of the study is that very few participants expressed that pilot practices were carried out prior to the implementation of the education policies. In fact, it is very important that a pilot implementation carried must be out in order to see the deficiencies of the policy before the implementation of a policy. According to the survey, the Ministry of Education takes responsibility for the implementation of the education policy in Turkey. For to implementation of the education policy in Turkey some conditions have been met such as; physical conditions, in-service training, policy promotion work, the separation of the necessary budget, meeting the teachers' needs, taking the opinions of relevant units, making the necessary legislative work and sending the practituners written instructions. On the other hand the number of respondents who said they applied without any preparation of educational policy in Turkey is not low. The most important phase of the educational policy process is practice. Fitz et al. (1994) defines the policy implementation process as the phase of transforming policy objectives into action (Kapt1, 2011, p. 33). According to 6 participants, pilot implementation of some policies in Turkey have been made. Pilot studies provide a good opportunity to analyze educational policies. However, with regard to the practics made so far in Turkey, instead of correcting the resulting deficiencies, these failures have been ignored and their applications have been shown as successful. According to research, education policies implemented in Turkey are monitored by the Central Organization.

According to the substantial number of participants (13), educational policies implemented in Turkey haven't been monitored. Permanent change of ministers and bureaucrats, hinders the accurate monitoring of the implementation of education policies in Turkey. It is possible to say that the participants did not have a clear view on interfering with the negativities that emerged in the monitoring of the implemented training policies. According to the research results educational policies implemented in Turkey are evaluated largely. Evaluation can be defined as determining the effectiveness of an education policy and determining whether the objectives have been achieved or not. Evaluation is to learn about the outcome of education policy. According to the results of the evaluation, the number of people who said that the policies were changed and the number of those who said that no changes were made in the policies were close to each other. Participants do not have a clear view on this issue. Making education policy is not merely the writing and application of law texts or other legislation. After this stage, the policy process seeks answers to questions such as whether the 
Uysal

desired goals are achieved, what the implementation results are and what other changes are needed (Hall, 2011, cited in Çevik \& Demirci, 2012, p. 18). According to the result of the evaluation, the policies applied have been continued, or necessary corrections are made or terminated. However, it's possible to say that the policy changes in Turkey depend on the change of ministers or bureaucrats or the political influences; they don't depend on the evaluation results. 